\title{
Research on Environmental Comparison and Selection for Different Span Schemes of Sea-crossing Bridge
}

\author{
Z.L. LIN ${ }^{1}$, Y.J.WU ${ }^{1}$, Q.S. LI $^{1}$, J.ZHANG ${ }^{1}$ \\ ${ }^{1}$ The Third Institute of Oceanography, State Oceanic Administration, Fujian, Xiamen
}

\begin{abstract}
KEYWORD: Sea-crossing Bridge; Span; Environmental Comparison and Selection
ABSTRACT: Environmental comparison and selection is an important measure to prevent and relieve adverse environmental impacts of construction project, and the comparison and selection of different span schemes is one of the priorities for environmental impact assessment of Sea-crossing bridge project. This research takes Shacheng Harbor Sea-crossing Grand Bridge as an example to forecast and evaluate the environmental impact of three types of different span schemes of 50m, $60 \mathrm{~m}$ and $80 \mathrm{~m}$ from four aspects including tidal flux change, diffusion of suspended sediment from construction, ship navigation and bridge pier occupation; meanwhile, it also considers the investment cost of different span schemes and puts forward the recommended scheme through comprehensive comparison and selection.
\end{abstract}

\section{INTRODUCTION}

In the last ten years, with the rapid development of marine economy, road transport, the infrastructure of regional economic development, also got substantial development in the coastal areas of our country. As a key component of coastal road traffic, sea-crossing bridges have been widely applied with the rapid development of highway bridge construction in our country.

Pier construction of sea-crossing bridges will have various impacts on the marine environment, including the impact on the changes of hydrological dynamics and erosion and deposition, the impact of suspended sediment from construction on seawater quality and sediment and the impact of bridge pier occupation on marine ecology such as benthic organism, etc. Among them, bridge pier construction has long-term and cumulative impact on hydrological dynamics and erosion and deposition, which directly affects waters flow velocity, flow direction and flux, thus resulting in the changes of erosion and deposition in the sea area, community and structure of marine ecosystem, etc. Therefore, it becomes the key in environmental impact assessment on sea-crossing bridges. The impact of bridge pier construction on the changes of hydrological dynamics and erosion and deposition in the sea area depends on the number and size of piers. Namely, it is closely related to bridge span scheme, so the paper is planning to take Shacheng Harbor Sea-crossing Grand Bridge as an example to analyze the impacts of different span schemes on marine environment and make environmental comparison and selection.

\section{RESEARCH SCHEMES}

Shacheng Harbor Sea-crossing Grand Bridge is located in the middle section of Shacheng Harbor of Fujian Province, a main bridge of North Branch Bridge crossing the waters between North Shore and Qingyu Island. After it landed on Qingyu Island, South Branch Bridge was built to cross the waters between Qingyu Island and South Shore. Please refer to Figure 1. for the geographic location. The main bridge of North Branch Bridge considers about navigation, using twin-tower double cable plane mixed cable-stayed bridge and piers are not set on the sea. While, South Branch Bridge adopts continuous box girder scheme(Xiaobin,Wang et al. 2013). Since Northern Branch Bridge doesn't have piers set on the sea, the impact of this sea-crossing bridge construction on the changes of hydrological dynamics and erosion and deposition in this sea area mainly comes from the construction of piers of South Branch Bridge, for which, three different span schemes of $50 \mathrm{~m}, 60 \mathrm{~m}$ and $80 \mathrm{~m}$ are considered for comparison and selection. The main work amount and investment estimate of different span schemes are as shown in the following Table 1. 


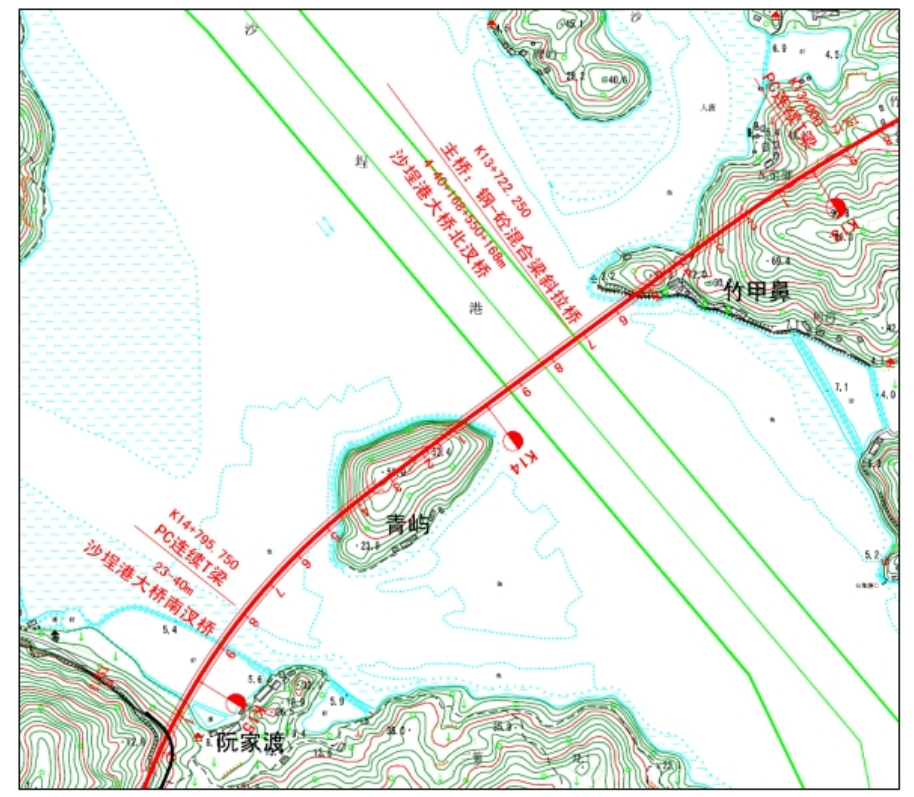

Figure 1. Geographic Location of Case Study

Table 1 Main Work Amount and Investment Estimate of Different Span Schemes

\begin{tabular}{|c|c|c|}
\hline $\begin{array}{l}\text { Scheme of } \\
\text { bridge type }\end{array}$ & Main work amount & $\begin{array}{c}\text { Investme } \\
\text { nt } \\
\text { estimate }\end{array}$ \\
\hline $\begin{array}{c}18 \times 50 \mathrm{~m} \\
\text { Cast-in-situ } \\
\text { continuous } \\
\text { box girder }\end{array}$ & $\begin{array}{l}\text { Bridge length is } \\
911.5 \mathrm{~m} \text { and bridge } \\
\text { deck acreage is } \\
30535 \mathrm{~m}^{2} \text {. There are } 9 \\
\text { piers within southern } \\
\text { watercourse and } 5 \\
\text { piers on the island. }\end{array}$ & $\begin{array}{c}\text { RMB } \\
172.57 \\
\text { million } \\
\text { yuan }\end{array}$ \\
\hline $\begin{array}{c}15 \times 60 \mathrm{~m} \\
\text { Cast-in-situ } \\
\text { continuous } \\
\text { box girder }\end{array}$ & $\begin{array}{l}\text { Bridge length is } \\
911.5 \mathrm{~m} \text { and bridge } \\
\text { deck acreage is } \\
30535 \mathrm{~m}^{2} \text {. There are } 7 \\
\text { piers within southern } \\
\text { watercourse and } 4 \\
\text { piers on the island. }\end{array}$ & $\begin{array}{c}\text { RMB } \\
204.60 \\
\text { million } \\
\text { yuan }\end{array}$ \\
\hline $\begin{array}{l}11 \times 80 \mathrm{~m} \\
\text { Cast-in-situ } \\
\text { continuous } \\
\text { box girder }\end{array}$ & $\begin{array}{l}\text { Bridge length is } \\
890.0 \mathrm{~m} \text { and bridge } \\
\text { deck acreage is } \\
29815 \mathrm{~m}^{2} \text {. There are } 5 \\
\text { piers within southern } \\
\text { watercourse and } 3 \\
\text { piers on the island. }\end{array}$ & $\begin{array}{c}\text { Rmb } \\
392.71 \\
\text { million } \\
\text { yuan }\end{array}$ \\
\hline
\end{tabular}

\section{RESEARCH METHOD}

The discrepancy of the impacts of different span schemes on marine environment is mainly embodied in the discrepancy of how many bridge piers will be used. Marine environmental impacts are mainly embodied in the environmental impact on marine hydrological dynamics and erosion and deposition, impact of suspended sediment from construction on the marine ecological environment, 
impact on ship navigation environment, as well as the impact of bridge pier occupation on marine ecology. The changes of marine hydrological dynamics and erosion and deposition are closely related to the change of tidal flux, so tidal flux change indicator is selected for comparison. Bridge pier construction adopts steel pile casing cofferdam, and the suspended sediment from construction has little impact; for the status quo of South Branch Bridge, its main navigation vessels are small fishing boats, and the three kinds of schemes can all meet the requirements of ship navigation, having few impacts on ship navigation; so qualitative analysis is adopted for the impact of suspended sediment from construction and ship navigation. For the impact of bridge pier occupation on marine ecology, comparison and selection are conducted according to the piers occupying acreage.

\section{RESEARCH RESULTS}

\section{Impact of tidal flux(Jinyan,Yang et al. 2014)}

Table 2 shows three different span schemes of $50 \mathrm{~m}, 60 \mathrm{~m}$ and $80 \mathrm{~m}$ of South Branch Bridge to verify the sectional tidal flux changes of south and north watercourses on Qingyu Island in the period of rising tide and falling tide before and after the construction of Shacheng Harbor Sea-crossing Grand Bridge in spring tide. We could see from the table that the tidal fluxes at the south and north watercourses of Qingyu are obvious in contrast; the sectional tidal flux at north watercourse occupies more than $80 \%$, far greater than south watercourse, which shows that north watercourse is the main channel of tide. Before the construction, the ebb tide flux of south watercourse is $19.9 \%$ and rising tide flux only $15.7 \%$.

After $50 \mathrm{~m}$ span scheme is built, the tidal fluxes at south and north watercourses will be adjusted; the falling tide flux at south watercourse will be reduced by 5.3 million $\mathrm{m}^{3}$, with a decrease rate of $14.1 \%$, and rising tide flux will be reduced by 6.06 million $\mathrm{m}^{3}$, with a decrease rate of $-18.6 \%$. It is because the north watercourse is deeper that the increase of tidal flux change is not obvious, with $3.5 \%$ as increase rate of falling tide flux at north watercourse and $3.5 \%$ as increase rate of rising tide flux.

After $60 \mathrm{~m}$ span scheme is implemented, the falling tide flux between south and north watercourses will be adjusted by \pm 3.1 million $\mathrm{m}^{3}$, with $-8.3 \%$ as decrease rate of falling tide flux at south watercourse and $2.1 \%$ as increase rate of falling tide flux at north watercourse; the rising tide flux between south and north watercourses will be adjusted by \pm 3.69 million $\mathrm{m}^{3}$, with $-11.4 \%$ as decrease rate of rising tide flux at south watercourse and $2.1 \%$ as increase rate of rising tide flux at north watercourse.

After $80 \mathrm{~m}$ span scheme is implemented, the falling tide flux between south and north watercourses will be adjusted by \pm 2.29 million $\mathrm{m}^{3}$, with $-6.1 \%$ as decrease rate of falling tide flux at south watercourse and $1.5 \%$ as increase rate of falling tide flux at north watercourse; the rising tide flux between south and north watercourses will be adjusted by \pm 2.74 million $\mathrm{m}^{3}$, with $-8.4 \%$ as decrease rate of rising tide flux at south watercourse and $1.6 \%$ as increase rate of rising tide flux at north watercourse. 
Table 2 Flux Changes Upon Tide Rising and Falling at South and North Watercourses of Qingyu Before and After the Construction of Shacheng Harbor Seacrossing Grand Bridge

(Verification of Spring Tide)

\begin{tabular}{|c|c|c|c|c|c|c|c|c|c|c|c|c|}
\hline \multirow[b]{2}{*}{ Period } & \multirow[b]{2}{*}{$\begin{array}{c}\text { Watercours } \\
\mathrm{e}\end{array}$} & \multicolumn{2}{|c|}{ Before construction } & \multicolumn{3}{|c|}{$\begin{array}{c}\text { After construction } \\
\text { (South Branch Bridge of 50m span) }\end{array}$} & \multicolumn{3}{|c|}{$\begin{array}{c}\text { After construction } \\
\text { (South Branch Bridge of } 60 \mathrm{~m} \text { span) }\end{array}$} & \multicolumn{3}{|c|}{$\begin{array}{c}\text { After construction } \\
\text { (South Branch Bridge of } 80 \mathrm{~m} \text { span) }\end{array}$} \\
\hline & & $\begin{array}{l}\text { Tidal flux } \\
\left(* 10^{4} \mathrm{~m}^{3}\right)\end{array}$ & $\begin{array}{r}\text { Ratio } \\
(\%)\end{array}$ & $\begin{array}{l}\text { Tidal flux } \\
\left(* 10^{4} \mathrm{~m}^{3}\right)\end{array}$ & $\begin{array}{c}\text { Change tidal } \\
\text { flux } \\
\left(* 10^{4} \mathrm{~m}^{3}\right)\end{array}$ & $\begin{array}{l}\text { Change } \\
\text { rate }(\%)\end{array}$ & $\begin{array}{l}\text { Tidal flux } \\
\left(* 10^{4} \mathrm{~m}^{3}\right)\end{array}$ & 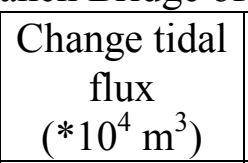 & $\begin{array}{l}\text { Change } \\
\text { rate }(\%)\end{array}$ & $\begin{array}{l}\text { Tidal flux } \\
\left(* 10^{4} \mathrm{~m}^{3}\right)\end{array}$ & $\begin{array}{c}\text { Change tidal } \\
\text { flux } \\
\left(* 10^{4} \mathrm{~m}^{3}\right)\end{array}$ & $\begin{array}{l}\text { Change } \\
\text { rate }(\%)\end{array}$ \\
\hline \multirow{2}{*}{$\begin{array}{l}\text { Fallin } \\
\text { g tide }\end{array}$} & \begin{tabular}{|c|} 
South \\
watercourse
\end{tabular} & 3750 & 19.9 & 3220 & -530 & -14.1 & 3440 & -310 & -8.3 & 3521 & -229 & -6.1 \\
\hline & \begin{tabular}{|c|} 
North \\
watercourse
\end{tabular} & 15060 & 80.1 & 15590 & 530 & 3.5 & 15370 & 310 & 2.1 & 15289 & 229 & 1.5 \\
\hline \multirow{2}{*}{$\begin{array}{c}\text { Rising } \\
\text { tide }\end{array}$} & $\begin{array}{c}\text { South } \\
\text { watercourse }\end{array}$ & 3248 & 15.7 & 2642 & -606 & -18.6 & 2879 & -369 & -11.4 & 2974 & -274 & -8.4 \\
\hline & \begin{tabular}{|c|} 
North \\
watercourse
\end{tabular} & 17469 & 84.3 & 18075 & 606 & 3.5 & 17838 & 369 & 2.1 & 17743 & 274 & 1.6 \\
\hline \multicolumn{2}{|c|}{$\begin{array}{l}\text { Number of piers in } \\
\text { south watercourse }\end{array}$} & \multicolumn{2}{|l|}{0} & \multicolumn{3}{|c|}{9} & \multicolumn{3}{|c|}{7} & \multicolumn{3}{|c|}{5} \\
\hline
\end{tabular}


We can see that after Shacheng Harbor Sea-crossing Grand Bridge was built, the piers of South Branch Bridge have had certain water resistance effect. The larger spacing between piers is, the smaller impact on the tidal flux between south and north watercourses is.

\section{Impact of suspended sediment from construction}

The increase of suspended sediment in the water caused by construction mainly takes place in the construction phase of bridge pier foundation. The piers of this project adopted pile foundation which supposed to adopt bored pile and steel pipe pile platform construction scheme; bearing platform and piers adopted cast-in-situ concrete for construction; the bottom elevation of bearing platform was controlled in accordance with nonexposure of bearing platform bottom pile foundation when water level is low; jacket cofferdam (steel cofferdam) was adopted in construction. This project adopted the technology of steel casing bored pile and steel cofferdam pouring bearing platform in the process of bridge pier foundation, so few sediment poured into the sea in the process of bridge pier foundation construction.

The difference of the impacts from suspended sediment with different spans is mainly embodied in how many piers will be used; the more the number of piers is, the greater the impact is; on the contrary, the less the number of piers is, the less the impact is. Therefore, $50 \mathrm{~m}$ span scheme has the greatest impact of suspended sediment from construction, successively following with $60 \mathrm{~m}$ span scheme and $80 \mathrm{~m}$ span scheme, the least one.

\section{Imapct on ship navigation}

Large ship navigation is considered for the North Branch Bridge of this sea-crossing bridge; and currently South Branch Bridge mainly allows the navigation of small fishing boats below 200 horsepower. The construction of piers objectively increases the difficulty in the navigation of small fishing boats. The three schemes of $50 \mathrm{~m}, 60 \mathrm{~m}$ and $80 \mathrm{~m}$ all can meet the navigation requirement of ships, so they have little impact on ship navigation basically; the larger the span is, the less the impact is; therefore, $50 \mathrm{~m}$ span scheme has the greatest impact, successively following with $60 \mathrm{~m}$ span scheme and $80 \mathrm{~m}$ span scheme, the least one.

\section{Impact of bridge pier occupation}

For $50 \mathrm{~m}$ span scheme, there are totally 9 bridge piers in south watercourse, with each of them occupying an area of $9.7 * 9.7 * 2 \approx 200 \mathrm{~m}^{2}$, accounting for about $0.18 \mathrm{hm}^{2}$ of sea area in total. For $60 \mathrm{~m}$ span scheme, there are totally 7 bridge piers in south watercourse, with each of them occupying an area of about 1.05 times more than that of $50 \mathrm{~m}$ span, accounting for about $0.15 \mathrm{hm}^{2}$ of sea area in total. For $80 \mathrm{~m}$ span scheme, there are totally 5 bridge piers in south watercourse, with each of them occupying an area of about 1.1 times more than that of $50 \mathrm{~m}$ span, accounting for about $0.11 \mathrm{hm}^{2}$ of sea area in total.

Table 3 Comparison and Selection of Impacts of Different Spans on Marine Environment

\begin{tabular}{|c|c|c|c|c|c|}
\hline \multicolumn{3}{|c|}{ Environmental element } & $50 \mathrm{~m}$ & $60 \mathrm{~m}$ & $80 \mathrm{~m}$ \\
\hline \multirow{4}{*}{$\begin{array}{l}\text { Chang } \\
\text { e rate } \\
\text { of tidal } \\
\text { flux } \\
(\%)\end{array}$} & $\begin{array}{l}\text { North } \\
\text { water- }\end{array}$ & $\begin{array}{l}\text { Fall- } \\
\text { ing } \\
\text { tide }\end{array}$ & 3.5 & 2.1 & 1.5 \\
\hline & course & $\begin{array}{l}\text { Rising } \\
\text { tide }\end{array}$ & 3.5 & 2.1 & 1.6 \\
\hline & South & $\begin{array}{l}\text { Fallin } \\
\text { g tide }\end{array}$ & -14.1 & -8.3 & -6.1 \\
\hline & $\begin{array}{l}\text { Water- } \\
\text { course }\end{array}$ & $\begin{array}{l}\text { Rising } \\
\text { tide }\end{array}$ & -18.6 & -11.4 & -8.4 \\
\hline \multirow{2}{*}{\multicolumn{3}{|c|}{$\begin{array}{l}\text { Impact of suspended } \\
\text { sediment from con- } \\
\text { struction } \\
\text { Impact on ship naviga- } \\
\text { tion environment }\end{array}$}} & Max. & Less & Min. \\
\hline & & & Max. & Less & Min. \\
\hline \multicolumn{3}{|c|}{$\begin{array}{l}\text { Sea area occupied by } \\
\text { bridge piers }\left(\mathrm{hm}^{2}\right)\end{array}$} & 0.18 & 0.15 & 0.11 \\
\hline
\end{tabular}

By synthesizing the comparison and selection in Table 3, we could conclude that the $50 \mathrm{~m}$ span scheme, with the least investment cost, has the largest impact on environment; 80m span has the least impact on environment with the biggest span; considering both environment and cost, we assess that the impact of $60 \mathrm{~m}$ span on 
tidal flux of south watercourse is within the acceptable scope of $10 \%$ and the relatively higher rate of investment is reachable. Therefore, this research recommends adopting $60 \mathrm{~m}$ span.

\section{CONCLUSION}

Scheme comparison and selection is an important part of environmental impact assessment and the core part in environmental impact assessment work. The study of scheme comparison and selection can not only provide technical supports in scheme selection for construction unit, but also provide scientific references for project competent department; it's an important method to realize the purpose of environmental impact assessment.

The impact of span of sea-crossing bridge on marine environment is: the larger the span and the less the number of piers is, the less the impact is; but since the size of span directly depends on investment cost, which means the larger the span is, the higher the investment is. Therefore, in the actual environmental impact assessment, both environment and cost shall be taken into consideration in scheme comparison and selection. In this way, scheme comparison and selection result could be practical and feasible.

\section{REFERENCES}

[1] Xiaobin,Wang. Qizhuo,Liu. Dan,Zheng.et al., 2013. Feasibility Study on Passageway for Fujian Shacheng Harbor Overseas Highway of Ningbo-Dongguan National Highway. Fuzhou:Fujian Communications, Planning \& Design Institute.

[2] Jinyan, Yang. Dongsheng, Yu 2015. Numerical Simulation Study on Shacheng Harbor Sea-crossing Grand Bridge Project in Fuding-Qinyu Section of Shenyang-Haikou Complex Line. Xiamen: The Third Institute of Oceanography, State Oceanic Administration. 